\title{
The impact of energy consumption on economic growth in developed and post-transition countries of European Union*
}

\author{
Tanja Fatur Šikić ${ }^{1}$
}

\begin{abstract}
This paper aims to investigate the impact of renewable and non-renewable energy consumption on economic growth. Analysis was conducted for 16 developed EU member states over the period from 1990 to 2018 and 11 post-transition EU member states over the period from 1995 to 2018. We also compared obtained results with results for the period until 2014. The pooled mean group (PMG) model was used to capture dynamic relationship in a short and long run. The empirical results show that consumption of both energy sources has an impact on economic growth in the long run in both groups of countries. However, the results differ between the developed and post-transition EU countries. In developed EU countries renewable energy consumption has a negative impact on economic growth, while non-renewable energy consumption has a positive impact. In posttransition EU countries results are opposite, meaning that in these countries there is a tendency to shift from less efficient and more polluting energy sources to more efficient energy options which can be a stimulus to economic growth.
\end{abstract}

Key words: non-renewable and renewable energy consumption, economic growth, developed and post-transition EU countries

JEL classification: $Q 43, O 44, C 33$

\section{Introduction}

Energy is considered to be a crucial input in the process of economic growth. Sustainable economic growth necessitates sufficient and continuous availability of energy input. Disruption in the energy supply raised the public and academic

\footnotetext{
* Received: 02-11-2020; accepted: 28-12-2020

1 Real Estate Valuation Advisor, Primorje-gorski kotar County, Department for Physical Planning, Construction and Environmental Protection. Riva 10, 51000 Rijeka, Croatia. Scientific affiliation: energyeconomics.E-mail: tanja.fatur@gmail.com.
} 
awareness of the importance of energy in the economic growth of countries. The impact of energy consumption on economic growth is of crucial importance in the international debate on global warming and the reduction of greenhouse gas emissions. Furthermore, since the world's leading economies agreed on the Kyoto Protocol in 2005 to limit their greenhouse gas emissions relative to the amounts emitted in 1990, the information of this relationship has become increasingly important (Dobnik, 2011). Nowadays, the energy consumption per capita is one of the indicators that describe the economic development of a country. It is well known that the spread of energy consumption is still unequal. There are developed or developing countries "absorbing" a great amount of energy and also countries less developed, that are only consuming a thin slice of the world's energy pie (the case of African countries). The relationship between economic growth and energy consumption is not constant, but it changes with time and driven by the national differences (Pirlogea and Cicea, 2012).

The EU is the largest importer of primary energy in the world. More than half of energy consumption in the EU (58\% in 2018) comes from imports, and the high proportion of imports is concentrated on a small number of countries (Eurostat, 2020) Furthermore, there is little diversification of supply lines and diversity in the use of energy resources. This makes the EU more sensitive to the political and economic impacts of countries from where they import energy and more sensitive to seasonal oscillations in energy production, which negatively affects investment decisions and economic stability. Among this, EU is also facing challenges such as high and unstable energy prices, rising global energy demand, security risks affecting producer and transit countries, rising threats to climate change, slow progress in energy efficiency, challenges brought by an increasing share of renewable energy sources and the need for greater transparency, further integration and interconnection of the energy market. In the future, is expected that the demand for energy to continue its upward trend. Another expected phenomenon, which started a long time ago and continues today, is the substitution among energy forms. Now the renewable energy is expected to take the lead in the race with fossil fuels.

For the last twenty years, the EU countries have been working on the creation of the internal energy market and energy union. The Energy Union package aims to ensure the EU, and its citizens, with a favourable, safe and sustainable energy. Specific measures include, among other things, energy security, energy efficiency and decarbonisation (European Council, 2015). However, the EU includes a heterogeneous group of countries. Between developed and post-transition EU member countries there are huge differences in the availability of own sources of energy, infrastructure, distribution system, price structure, as well as in many other factors (Vlahinić-Dizdarević, 2011). Most importantly, carbon intensive fuels account for a much higher share of the energy mix in the post-transition compared to developed EU countries. This is primarily due to a considerably higher overall 
reliance on solid fuels. While solid fuels, in 2017 , accounted for only $10 \%$ of gross inland energy consumption in developed EU countries, they represented $30 \%$ of the energy mix in post-transition EU countries (Eurostat, 2020). Many post-transition EU Member countries depend heavily on a relatively small number of suppliers, especially with regard to gas supply, which makes them vulnerable to energy supply disruptions. In addition, a major problem is EU's aging energy infrastructure (Farfan Orozco, 2017), as well as poorly integrated energy markets, especially cross-border.

Post-transition EU countries have come a long way in the past 20 years. In 2018 the gross domestic product (GDP) growth rate of post-transition EU countries has doubled compared to the original EU member countries (World development indicators, 2020). They have improved their energy efficiency vastly and are narrowing the gap with the old EU member states. However, part of that improvement was due to abandonment of Soviet-era heavy industry. Further reductions in energy intensity are harder, and with development of renewable energy, will require large financial investments.

In line with the EU's climate and energy policy targets by 2030 and 2050, alongside the targets set by the European Green Deal (European Commission, 2019), the EU needs to reduce its overall dependence on fossil fuels and reduce greenhouse gas emissions. To secure new energy sources and reduce greenhouse gas emissions, the EU has focused on increasing the use of renewable energy sources and improving energy efficiency. The EU reform model and creating Energy union has significantly determined reforms in post-transition countries, especially in the electricity sector (European Commission, 2017).

A new EU energy package of laws has been introduced that has significantly affected the dynamics and direction of restructuring and liberalization of the electricity and natural gas market. Given the major changes that are expected in the energy sector and in all other sectors due to the energy transition towards a low carbon future, this paper is focused on examining the impact of renewable and nonrenewable energy consumption on economic growth in 16 developed an 11 posttransition EU countries. The choice to divide EU countries in developed and posttransition EU countries (countries that entered the EU after 2004) to some extent reduces the problem of heterogeneity among the countries. All the post-transition EU countries considered in the study have covered a similar path of modernizing their economies during the last 20 years, which has led to their membership in the EU. Because of this, they had to comply with the requirements regarding environment protection. As neighbours, the countries have similar climate. However, they differ with respect to the ways of obtaining energy sources and the structure of energy production (Papiez and Smiech, 2013).

The EU has adopted a growing set of policy instruments to drive the energy transition toward the goal of carbon neutral EU economy by 2050 where renewable 
energy sources have emerged as an important component in the energy consumption mix. Given that energy in many countries is crucial for the process of economic growth, questions are raised as to whether all energy sources contribute equally to economic growth in EU countries and what is the difference in the use of individual energy sources in developed compared to post-transition EU countries. The main hypothesis is that consumption of renewable and non-renewable energy sources has a significant impact on economic growth in EU countries. Although new and more sophisticated econometric methods have been developed over the years to (better) determine and understand this relationship, an increasing number of published empirical studies on the relationship between energy and GDP result in conflicting, inconsistent results, which in turn prevents creating credible energy programs and measures (see Menegaki, 2014). Analysis conducted in this study strives to correct the shortcomings of the majority of studies published so far, primarily referring to the use of the multivariate framework and the corresponding quantitative method. Second, to avoid the potential problem of omitted variables, the research applies the Cobb-Douglas production function which includes capital and labour. Thirdly, the sign and size of individual coefficients is evaluated in relation to comparative models in which the relationship between consumption of renewable and nonrenewable energy sources and economic growth is investigated.

The remainder of the paper is organized as follows: Section 2 presents a review of the existing literature. The model used in analysis is described in Section 3, followed by the empirical data and analysis in Section 4 and empirical results in Section 5. Finally, conclusion and policy implications are provided in Section 6.

\section{Literature review}

The relationship between energy consumption and economic growth has been subject of intense research in the last three decades. However, the empirical evidence remains controversial and ambiguous to this date. The existing literature reveals that empirical studies differ substantially and are not conclusive to present policy recommendation that can be applied across countries.

Following the study of Kraft and Kraft (1978), an extensive number of empirical works have assessed the empirical evidence employing Granger causality and cointegration model. Ozturk (2010) and Menegaki (2014) provide an extensive review survey of the studies on the empirical results from causality tests between energy consumption and economic growth.

The energy consumption-economic growth nexus can be analysed under four hypotheses. The growth hypothesis assumes energy as a major source of input into the growth process, and unidirectional causality exists from energy consumption 
to economic growth. In this scenario, energy conservation policies will have a negative impact on economic growth. The conservation hypothesis implies that economic growth causes consumption of energy. Under this situation, conservation policy will not affect economic growth. The feedback hypothesis implies a bidirectional relationship between energy consumption and economic growth. This hypothesis suggests any change in energy consumption will affect economic growth with a reverse effect. The neutrality hypothesis indicates that energy consumption and economic growth are independent and do not affect each other. The literature over the past decades has produced varied findings across countries under each of these hypotheses. No consensus has emerged from these studies. Most of them focus on just aggregated energy consumption. In this study we will test the presence of growth hypothesis between renewable and non-renewable energy consumption and economic growth in EU countries.

Increased energy demand, the need to achieve sustainable development goals, and negative effects of non-renewable sources on environment are important reasons that motivate countries to promote renewable energy. According to IRENA (2015) 164 countries have accepted at least one of the goals of increasing renewable energy sources. This fact encourages researchers to integrate the renewable energy variable when looking at the relationship between energy consumption and economic growth. Recently, the literature has started paying more attention to the effect of energy consumption on economic growth in terms of renewable and non-renewable energy sources. However, the magnitude and the direction of this effect is still unclear. According to Tugcu et al. (2012), one of the reasons for focusing on this topic is the vision of sustainable development. Today, a large number of countries have agreed on conserving energy and reducing carbon dioxide (CO2) emissions. This has increased the attractiveness of energy consumption related studies. However, the key dynamic in those studies is the consumption of renewable energy sources. With the growing importance of sustainable development, researchers are more interested in the effects of renewable energy consumption on economic growth.

Due to a large number of studies, analysis of literature in this area will be focused on the literature relating to the EU countries. Tiwari (2011) revealed that while the growth rate of non-renewable energy consumption has a negative impact, the growth rate of renewable energy consumption has a positive impact on the growth rate of GDP for 14 EU, Norway, Switzerland and Turkey. Similar results were found by Uçan, Aricioglu and Yucel (2014) for EU15 and Ito (2017) for 42 developed countries. Apergis and Payne (2012) found bidirectional causality between renewable and non-renewable energy consumption measures and economic growth in both short and long run for 80 developed and developing countries. The same results were found by Salim et al. (2014) for OECD countries. Tugcu et al. (2012) assessed the long-run and causal relationships between renewable and non- 
renewable energy consumption and economic growth for G7. The results, estimated under a classical production function, demonstrate that there is bidirectional causality between non-renewable energy and growth in all G7 countries. Pirlogea and Cicea (2012) found long-term impact of all types of energy on economic growth for the EU-27 and for oil in Spain and Romania. Jebli and Youssef (2015) analysed the causal relationship between renewable and non-renewable energy consumption, economic growth and trade in the 69 countries. They found positive unidirectional causality from renewable and non-renewable energy consumption to real GDP. Menegaki (2011) examined the casual relationship between economic growth and renewable energy for $27 \mathrm{EU}$ countries in a multivariate panel framework over the period from 1997 till 2007. The results indicate the evidence of the neutrality hypothesis.

There are few empirical studies on the relationship between economic growth and energy in the new Member States of the EU. Ozturk and Acaravci (2010) analysed causal relationship between energy and economic growth in Albania, Bulgaria, Hungary and Romania from 1980 to 2006. They found evidence of a long-run relationship between energy use and real GDP and evidence of strong bidirectional Granger causality between these variables only in Hungary, while in Albania, Bulgaria and Romania the results indicate the evidence of the neutrality hypothesis. Sharma (2010) analysed the relationship between energy and economic growth in 66 countries from 1986 to 2005 . They found that both electricity and non-electricity type energy variables have strong impacts on economic growth of EU. Bercu et al. (2019) analysed the long-term relationship between energy consumption, economic growth and good governance for 14 Central and Eastern EU (CEE) countries, over the period 1995-2017. They found that there is a causal relationship between electricity consumption and economic growth, underlining the fact that deficiencies in the energy system lead to slowing economic growth. The study also shows that good governance influences electricity and GDP consumption. Some authors concentrated on the analysis of relationship between economic growth and renewable energy. Alper and Oguz (2016) analysed the relationship between these variables in the new EU countries and concluded that there is a statistically significant impact on economic output only for Bulgaria, Estonia, Poland and Slovenia. Koçak and Şarkgüneşi (2017) analysed the group of economies in the Balkans and at the Black Sea, concluding that, in Romania, the hypothesis of the bi-directional causality was validated, while in Greece and Bulgaria only the positive influence of renewable energy consumption on the economic growth was confirmed. Šimelyte and Dudzevičiūtė (2017) analysed 28 EU countries, concluding that renewable energy consumption is boosting economic growth in 12 countries. The neutrality hypothesis has been validated in Luxembourg and Portugal, while the conservation hypothesis has been proven in Czech Republic, Hungary, Latvia, Lithuania, Romania, and Spain. The findings by Furuoka (2017) indicate that there exists a unidirectional causality from economic development to renewable energy consumption in Estonia, Latvia and Lithuania. Marinas et al. (2018) 
examined the casual relationship between economic growth and renewable energy for 10 EU member states from CEE in the period 1990-2014. The results indicate a bidirectional causality between renewable energy consumption and economic growth in the long run. In the short run there is no causality in Romania and Bulgaria, while in Hungary, Lithuania and Slovenia results confirm growth hypothesis.

A general conclusion from the studies reviewed in this section is that there is no consensus on existence or direction of causality between energy consumption and economic growth in the literature. Most studies are focused on developed countries, developing countries and the so-called countries with emerging markets. There is a smaller number of studies related to new EU countries or countries that entered EU after 2004. Reforms in the energy sector in the post-transition EU countries are carried out as part of a broader process of transition and structural adjustment. Macroeconomic framework of these reforms varies considerably between developed and post-transition EU countries. Therefore, the present study aims to contribute to the literature by identifying the impact of renewable and nonrenewable sources of energy on economic growth in developed and post-transition EU countries.

\section{The model}

For the analysis of the impact of energy consumption on economic growth, a large number of researches use the non-classical Cobb-Douglas production function to integrate energy consumption with production function (Ozturk, 2010). In addition, several recent studies integrate energy consumption by source (consumption of renewable and non-renewable energy sources) with the production function (Apergis and Payne 2010, 2012; Dogan, 2015; Omri et al., 2015; Salim et al., 2014; Šimelytė and Dudzevičiūtè, 2017). Energy can be classified into two categories; clean energy (renewable) and non-clean energy (non-renewable) and the production procedure uses both resources as sources of energy. In this paper a simple CobbDouglas production function was used, along with traditional inputs capital and labour, renewable and non-renewable sources of energy are utilized.

$$
G D P_{i t}=f\left(K_{i t} ; L_{i t} ; R E_{i t} ; N R E_{i t}\right)
$$

The subscripts $i$ and $t$ denote country and time period respectively. In the above model, $G D P$ is the dependent variable and represents real gross domestic production, $K, L, R E$, and $N R E$, are independent variables and stand for capital, labour, renewable, and non-renewable energy consumption, respectively. Eq. (1) can be parameterised as follows:

$$
G D P_{i t}=K_{i t}^{\beta 1 i} L_{i t}^{\beta 2 i} R E_{i t}^{\beta 3 i} N R E_{i t}^{\beta 4 i}
$$


The transformation of data series into natural logarithm avoids the problems associated with dynamic properties of the data series. The log transformation of the data series is a preferred approach, as each resulting coefficient in a regression equation can be interpreted as elasticities. The empirical equation is developed as follows:

$$
\ln G D P_{i t}=\beta_{1 i} \ln K_{i t}+\beta_{2 i} \ln L_{i t}+\beta_{3 i} \ln R E_{i t}+\beta_{4 i} \ln N R E_{i t}+\varphi_{i t}
$$

where $\beta_{l i}, \beta_{2 i}, \beta_{3 i}$ and $\beta_{4 i}$ are elasticities of output with respect to gross fixed capital formation, labour, renewable, and non-renewable energy consumption, $\varphi$ is the error term.

\section{Empirical data and analysis}

\subsection{The data}

Annual data for 16 developed EU countries from 1990 to 2018 and 11 posttransition EU countries from 1995 to 2018 were obtained from the World Bank Development Indicators and Eurostat. Malta is excluded from the research due to the lack of all the necessary data. Data for post-transition EU countries begins with year 1995 due to missing data for previous years for all variables needed. The multivariate frame-work includes real GDP (GDP) in constant 2010 US dollars, real gross fixed capital formation (K) in constant 2010 US dollars, labour force (L) in millions, renewable energy consumption (RE) and non-renewable energy consumption (NRE) in thousand tonnes of oil equivalent (TOE). Data for gross inland energy consumption of renewable energy was taken from Eurostat and includes wind power, solar power (thermal, photovoltaic and concentrated), hydroelectric power, tidal power, geothermal energy, biomass and the renewable part of waste. NRE is calculated by summarizing gross inland energy consumption of solid fossil fuels, oil and petroleum products and natural gas. To compare the results between countries, all variables are divided by the average population collected from the Eurostat. All variables are expressed in natural logarithms, so that the coefficients resulting from panel regressions can be interpreted as elasticities. The descriptive statistics is listed in the appendix. The descriptive statistics clearly indicates that there are large differences in data between both group of countries. It is clear that in developed EU countries the average GDP per capita and gross fixed capital formation per capita are three times higher than in post-transition EU countries, while the average consumption of renewable and non-renewable energy per capita is $30 \%$ and $60 \%$ higher.

EU countries are divided into developed and post-transition EU countries based on the following criteria. First, the 11 post-transition EU economies had similar 
trajectories regarding their economic development-the planned allocation of resources in the economy up to 1990 followed by transition towards a market economy, their accession to the EU in 2004 (the Czech Republic, Estonia, Hungary, Lithuania, Latvia, Poland, Slovakia, Slovenia), in 2007 (Bulgaria and Romania) and 2013 (Croatia) as a result of meeting certain common criteria. Secondly, there were some common features of their energy sector- high energy intensity, high dependence on solid fuels, little diversification of supply lines, high dependence on import of oil and gas from Russia, old and obsolete energy facilities, lack of capital for investing in rebuilding energy sector and inadequate institutional resources. The third is the fact that specialized literature neglected to analyse this group of economies despite the fact that the post-transition EU countries enjoy similar economic challenges and context.

The primary objective of the model is to test how renewable and non-renewable energy consumption affects the economic growth in the selected countries. To analyse the long-run and short-run relationship between variables, in the panel of 16 developed and 11 post-transition EU countries, Pooled mean group estimator (PMG) and Mean Group estimator (MG) were applied. We also did a comparison with results obtained until 2014.

The empirical analysis is divided into three steps. In the first step, we perform the panel unit root tests. In the second step we carry out Pedroni cointegration tests on the data. Finally in the third step to analyse the long-run and short-run relationship parameters, PMG and MG method is employed.

\subsection{The empirical analysis}

The first step in the estimation of dynamic panels was to test if the variables contain unit roots. In this study, five panel unit root tests were tested, namely Levin-LinChu (LLC) test (Levin et al. 2002), Im, Pesaran and Shin (IPS) test (Im et al., 2003), Fisher-type tests using Augmented Dickey-Fuller and Philips-Perron test (Maddala and $\mathrm{Wu}, 1999$ ) and Breitung test (Breitung, 2001). Table 2 presents the results of the panel unit root tests. It can be seen from Table 1 that each variable was integrated of order one, i.e. I(1). 
Table 1: Results of panel unit root tests

\begin{tabular}{|l|r|r|r|r|r|}
\hline \multicolumn{1}{|c|}{ Variables } & \multicolumn{1}{|c|}{ LLC test } & \multicolumn{1}{c|}{ IPS test } & $\begin{array}{c}\text { ADF-Fisher } \\
\text { test }\end{array}$ & PP-Fisher test & Breitung test \\
\hline Level & -1.23361 & 0.55403 & 46.9668 & 43.5777 & $-2.41698 * *$ \\
\hline GDP & $-2.02472 *$ & $-1.64811 *$ & 68.8815 & 46.1880 & $-4.36935 * * *$ \\
\hline$K$ & $-2.15487 *$ & -0.25137 & $79.1568 *$ & 52.7193 & 1.53430 \\
\hline$L$ & $-2.24844 *$ & 0.41873 & $82.5122 *$ & $81.6991 *$ & 3.84849 \\
\hline$N R E$ & $-1.80203 * *$ & $-1.63175^{*}$ & $78.2217 * *$ & $128.127 * * *$ & -0.40291 \\
\hline$R E$ & $-8.40361 * * *$ & $-7.75320 * * *$ & $159.868 * * *$ & $314.361 * * *$ & $-7.56591 * * *$ \\
\hline First difference & $-7.28852 * * *$ & $-8.74447 * * *$ & $176.074 * * *$ & $486.634 * * *$ & $-6.69363 * * *$ \\
\hline$\Delta \mathrm{GDP}$ & $-6.22900 * * *$ & $-7.91201 * * *$ & $160.314 * * *$ & $318.411 * * *$ & $-7.96059 * * *$ \\
\hline$\Delta K$ & $-5.71149 * * *$ & $-10.2379 * * *$ & $206.237 * * *$ & $876.429 * * *$ & $-6.58676 * * *$ \\
\hline$\Delta \mathrm{L}$ & $-10.3998 * * *$ & $-13.1903 * * *$ & $264.908 * * *$ & $1114.08 * * *$ & $-8.61760 * * *$ \\
\hline$\Delta N R E$ &
\end{tabular}

Notes: Deterministic intercept and trend included; $* * *, * *$ and $*$ indicate the test statistics are significant at $1 \%, 5 \%$, and $10 \%$ levels, respectively.

Source: Author's calculation

Given that each variable contains a panel unit root, the set of Pedroni's panel cointegration tests (Pedroni, 1999) were carried out to examine whether there was a long-term relationship between the variables used. The results obtained from the tests are presented in Table 2 .

Table 2: Pedroni results for panel cointegration tests

\begin{tabular}{|l|r|l|r|}
\hline \multicolumn{2}{|c|}{ Within dimension test statistics } & \multicolumn{2}{c|}{ Between dimension test statistics } \\
\hline Panel v-Statistic & $15.16030^{* * *}$ & Group rho-Statistic & 2.538609 \\
\hline Panel rho-Statistic & 1.409332 & Group PP-Statistic & $-6.607006 * * *$ \\
\hline Panel PP-Statistic & $-4.214487 * * *$ & Group ADF-Statistic & $-6.983725 * * *$ \\
\hline Panel ADF-Statistic & $-5.560384 * * *$ & & \\
\hline
\end{tabular}

Trend assumption: Deterministic intercept and trend. Lag selection: Automatic based on SIC with a max lag of 3 . Newey-West automatic bandwidth selection with Bartlett kernel. *** Denote rejection of null hypothesis of no cointegration at $1 \%$ significance level

Source: Author's calculation

Out of seven test statistics, five confirm the presence of cointegration among the variables. Therefore, according to the results, real GDP, real gross fixed capital formation, labour force, renewable, and non-renewable energy consumption share a long-run equilibrium relationship. 
Since the cointegration relationship was established, the PMG estimator proposed by Pesaran et al. (1999) was used in a panel of autoregressive distributed lag (ARDL) model. When a number of time series is relatively larger than cross sections, as is the case in this analysis, Pesaran and Smith (1995) show that the traditional panel techniques (FE, instrumental variables, GMM estimators) can produce inconsistent, and potentially very misleading estimates of the average values of the parameters in dynamic panel data model. The PMG model is used to identify the short-run and the long-run impact of selected independent variables on the economic growth. The basic assumptions of the PMG estimator are as follows: first, the error terms are serially uncorrelated and are distributed independently of the regressors, that is, the explanatory variables can be treated as exogenous; second, there is a long-run relationship between the dependent and explanatory variables; and third, the long-run parameters are the same across countries (Lee and Wang, 2015). Advantages of PMG model are that it allows intercept, slope coefficient and error variance to vary across countries, and therefore, to identify heterogeneity among countries of the panel. An alternative panel specification would be the MG estimator by Pesaran and Smith (1995) that does not account for the fact that some economic conditions may be the same across countries in the long run (Sulaiman and Abdul-Rahim, 2020)

The efficiency gain of PMG estimator comes from the hypothesis of heterogeneous short-run dynamics and identical long-run coefficient across countries. The PMG estimator allows assessing two types of relationship: a short-run relationship by testing the significance of the coefficients related to the lagged differences of economic and energy variables and a long-run relationship associated to the speed of adjustment coefficient or the error correction term (ECT). The ECT has to be negative to validate long-run equilibrium among the variables. A larger value of ECT implies a greater response of the variable to the deviation from longrun equilibrium while a low value indicates that any deviation from long-run equilibrium needs much longer time to force the variables back to it. A disadvantage of the PMG estimator is that, unless the available time series are long, a degrees of freedom problem is soon reached (Gemmell et al., 2016).

Next, according to the minimum levels of the Akaike criteria, an optimal lag of the ARDL model $(1,1,1,1,1)$ was chosen. Table 3 reports the results helping to choose the best estimation method by comparing the PMG estimates with those obtained by using MG method. The test of difference in these models is performed with the well-known Hausman test. 
Tanja Fatur Sikić • The impact of energy consumption on economic growth...

Table 3: Estimation results of the dynamic panel model.

\begin{tabular}{|c|c|c|c|c|c|c|}
\hline Variables & \multicolumn{3}{|c|}{16 developed EU countries } & \multicolumn{3}{|c|}{11 post-transition EU countries } \\
\hline $\begin{array}{l}\text { Long-run } \\
\text { coefficients }\end{array}$ & PMG & MG & $\begin{array}{c}\text { Results } \\
\text { in period } \\
1990-2014\end{array}$ & PMG & MG & $\begin{array}{c}\text { Results } \\
\text { in period } \\
1995-2014\end{array}$ \\
\hline \multirow{2}{*}{ K } & -0.019 & -11.734 & $0.416 * * *$ & $0.501 * * *$ & -0.133 & $0.628 * * *$ \\
\hline & $(0.0289)$ & $(-12.0755)$ & $(0.1276)$ & $(-0.1143)$ & $(-0.6778)$ & $(0.0472)$ \\
\hline \multirow{2}{*}{$\mathrm{L}$} & $-11.638 * * *$ & 5.678 & -0.470 & $-15.614 * * *$ & 3.426 & $0.593 *$ \\
\hline & $(-2.3301)$ & $(-15.0157)$ & $(0.5068)$ & $(-5.0578)$ & $(-5.3346)$ & $(0.3499)$ \\
\hline \multirow{2}{*}{ NRE } & $0.337 * *$ & -0.208 & $0.625 * * *$ & $-1.101 * * *$ & 0.014 & $-0.311 * *$ \\
\hline & $(-0.1361)$ & $(-6.354)$ & $(0.2091)$ & $(-0.2962)$ & $(-0.4567)$ & $(0.1387)$ \\
\hline \multirow{2}{*}{ RE } & $-1.005 * * *$ & 3.207 & $0.266 * * *$ & $0.689 * *$ & 1.578 & $0.096^{*}$ \\
\hline & $(-0.2495)$ & $(-4.4956)$ & $(0.0941)$ & $(-0.3009)$ & $(-1.5233)$ & $(0.0559)$ \\
\hline \multicolumn{7}{|c|}{ Short-run coefficients } \\
\hline \multirow{2}{*}{$\begin{array}{l}\text { Error correction } \\
\text { coefficients }\end{array}$} & $-0.064 * *$ & $-0.186 * *$ & $-0.215 * * *$ & $-0.246 * *$ & $-0.440 * * *$ & $-0.115 * * *$ \\
\hline & $(-0.0376)$ & $(-0.0743)$ & $(0.0456)$ & $(-0.0975)$ & $(-0.0534)$ & $(0.0195)$ \\
\hline \multirow{2}{*}{$\Delta \mathrm{K}$} & 0.016 & -0.48 & $0.164 * * *$ & $0.678 * * *$ & $0.497 * * *$ & $0.139 * * *$ \\
\hline & $(-0.2579)$ & $(-0.6207)$ & $(0.0186)$ & $(-0.1658)$ & $(-0.1458)$ & $(0.0177)$ \\
\hline \multirow{2}{*}{$\Delta \mathrm{L}$} & -1.345 & 0.88 & 0.128 & 0.246 & -1.099 & 0.084 \\
\hline & $(-1.5555)$ & -2.2241 & $(0.0806)$ & $(-3.1418)$ & $(-2.9699)$ & $(0.1736)$ \\
\hline \multirow{2}{*}{$\triangle \mathrm{NRE}$} & 4.112 & 4.711 & 0.009 & 0.206 & 0.173 & $0.124 * * *$ \\
\hline & $(-3.7867)$ & $(-4.6079)$ & $(0.0211)$ & $(-0.1275)$ & $(-0.1557)$ & $(0.0329)$ \\
\hline \multirow{2}{*}{$\Delta \mathrm{RE}$} & 0.189 & -0.256 & -0.012 & -0.200 & -0.925 & 0.030 \\
\hline & $(-0.2597)$ & $(-0.2661)$ & $(0.0154)$ & $(-0.414)$ & $(-0.7503)$ & $(0.0301)$ \\
\hline \multirow{2}{*}{ constant } & 0.032 & 9.578 & $2.198 * * *$ & $-2.163 * *$ & -1.166 & $0.432 * * *$ \\
\hline & $(-0.0497)$ & -21.557 & $(0.6510)$ & $(-0.8738)$ & $(-5.8903)$ & $(0.0687)$ \\
\hline $\begin{array}{l}\text { Number of } \\
\text { observations }\end{array}$ & 446 & 446 & 360 & 253 & 253 & 236 \\
\hline Number of groups & 16 & 16 & 15 & 11 & 11 & 11 \\
\hline \multirow{2}{*}{ Hausman test } & 1.75 & & & 5.36 & & \\
\hline & {$[0.789]$} & & & {$[0.620]$} & & \\
\hline
\end{tabular}

Note: The standard errors are in the parenthesis. The p-value for the Hausman specification test is given in square brackets. The asterisks *, **, ***, indicate significance level of $10 \%$, $5 \%$ and $1 \%$, respectively, all variables are expressed in logarithms.

Source: Author's calculation

Given that the Hausman tests points to panel homogeneity, a battery of diagnostic tests were performed, namely on heteroscedasticity, contemporaneous correlation among cross sections and non-correlation of variances across individuals. The results support the acceptation of the null hypothesis of the modified Wald test, 
pointing that there is no heteroscedasticity. According to Pesaran test there is no contemporaneous correlation. The Breusch-Pagan test rejects the hypothesis that the residuals are correlated but only for post-transition countries. Results of diagnostic tests is listed in the appendix.

\section{Results and discussion}

Using a PMG estimator, the results showed that in 16 developed EU countries, changes in consumption of renewable and non-renewable energy sources per capita have an impact on economic growth, but only in the long run. According to the given results, renewable energy consumption has a negative impact on economic growth. Although consumption of renewable energy has been continually growing, especially after the ratification of the Kyoto Protocol, it seems that by increasing consumption of renewable energy, GDP growth will decrease. This might be a result of political decisions carried out in some developed EU countries which decreased or stopped further investments in the renewable sources of energy and encouraged investments in fossil fuels due to lower prices of oil. According to IEA (2018), global investment in renewable energy declined by $7 \%$ in 2017 , it was the largest fall in over 15 years. It is interesting to notice that when the same variables were analysed in the period 1990 - 2014 renewable energy consumption had a positive and significant impact on economic growth. Between mid-2014 and early 2016, the global economy faced one of the largest oil price declines in modern history. The $70 \%$ price drop during that period was one of the three biggest declines since World War II, and the longest lasting since the supply-driven collapse of 1986 (World Bank Group, 2018).

According to the results in 11 post-transition EU countries, the change in the consumption of renewable and non-renewable energy per capita has a statistically significant impact on economic growth. The long-term renewable energy consumption coefficient is statistically significant at the $5 \%$ significance level, suggesting that if renewable energy consumption increases by $1 \%$, then GDP will increase by $0.68 \%$. This means that renewable energy could help expand access to energy in post-transition EU countries. When comparing results with analysis conducted until 2014 it is evident that the impact of renewable energy consumption increased dramatically due to high increase of renewable energy in post-transition EU countries. Increasing renewable energy consumption can be a very difficult goal, including uncertainties related to technology revenues and costs, availability of technology, lack of private sector involvement, or restrictions on government policies. The economic policies of individual post-transition EU countries must provide incentives to implement energy-efficient industries and increase investment in new energy capacities while diversifying energy sources in order to reduce energy dependence. 
Furthermore, the coefficient for consumption of non-renewable energy in posttransition countries is statistically significant but negative, which can be explained by the continuous decrease of non-renewable energy sources in post-transition EU countries. Same results are confirmed in analysis conducted until 2014. In 2017, in post-transition EU countries, the share of non-renewable energy in total energy consumption was $77 \%$, while in 1990 it was $91 \%$. Coal is still the main source of energy, although in 2017 its share was reduced to $30 \%$ compared to $46 \%$ in 1990 . The share of oil $(27 \%)$ and gas (19\%) did not change significantly, while consumption of renewable energy increased by four times, from 3\% in 1990 to $12 \%$ in 2017 . Hajko (2014) argues that if manufacturing processes, for example in the industrial sector, move away from energy-intensive activities while maintaining production, the innovation potential of such change will be expressed as negative causality. This innovation can be influenced by increased energy efficiency in existing production, but also by the motivation for structural change within the industry. The importance of the sign of causality is often overlooked in the literature. The sign of causality is usually assumed to be positive (Narayan and Popp, 2012). Among the few exceptions that acknowledge the importance of a sign of causality are Narayan and Popp (2012), Bowden and Payne (2009), and Sari and Soytas (2007). The long-run coefficient for capital is statistically significant, suggesting that if capital increases by $1 \%$, then GDP will increase by $0.50 \%$ while coefficient for labour is significant but negative in the long run. In the short run only capital significantly affects economic growth.

The results using PMG estimation method suggest that the error correction coefficients are significantly negative in both groups of countries, indicating the existence of a stable and converging long-run relationship between GDP and capital, labour, non-renewable and renewable energy. Therefore, it can be concluded that the deviation between economic activity and the selected set of independent variables from their long-run equilibrium relationship is gradually decreasing.

The results of the econometric analysis carried out on a set of developed and posttransition EU countries confirmed the main hypothesis that renewable and nonrenewable energy consumption has a statistically significant impact on economic growth. The presence of relationship from energy consumption to economic growth means that the availability of energy has a direct impact on economic activity and a prerequisite for achieving high growth rates in the region. Therefore, priority should be directed to energy management, manufacturing and distribution in order to avoid harmful effects of lack of energy. However, the results differ between the developed and post-transition EU countries. In developed EU countries renewable energy consumption has a negative impact on economic growth, while non-renewable energy consumption has a positive impact. In post-transition EU countries results are opposite.

The empirical finding that renewable and non-renewable energy consumption has an impact on economic growth does not necessarily imply that energy conservation 
will harm economic growth if energy-efficient production technologies are used. In fact, a reduction in energy consumption due to improvements in energy efficiency may raise productivity, which in turn may stimulate economic growth. Thus, a shift from less efficient and more polluting energy sources to more efficient energy options may establish a stimulus rather than an obstacle to economic development (Costantini and Martini, 2010). According to the results this is validated for posttransition EU countries, which evidently had decreased their consumption of nonrenewable energy, while increasing consumption of renewable energy.

Although the EU seeks to establish a single energy market and common energy goals for all member states, different energy policies need to be implemented for each group of countries. Energy intensity is still higher in the post-transition EU countries, it would be irresponsible to force a reduction in energy consumption in those Member States. Obtained research results represent a significant challenge for creators of economic and energy policy in the analysed countries. The above results have significant implications for developing economic policy, especially measures relating to state aid, as well as to conduct energy policy, in particular instruments and measures affecting energy savings. It is particularly important for post-transition EU countries to ensure stable energy sources and diversified supply routes in order to reduce vulnerability and increase the security of the energy system, thus providing a basis for long-term stable economic growth.

We highlight some limitations of our model in explaining the economic growth process considering renewables as an energy source. According to Bhattacharya et al. (2016) while the deployment of renewables depends on many factors within and across countries, it is important to take a long-term view of the deployment process considering cost, efficiency, infrastructure, regulatory barriers, and institutional structure of any country. For example, the integration of renewables with the grid is a major challenge as the grids are largely built to cater for fossil fuel generated baseload electricity. There are strong regulation perceptions, acting as a barrier for increase in renewable investment. We do not consider these factors which may directly or indirectly affect economic growth. Further, we could not include disaggregated data within the renewables due to unavailability of data for long period of time.

Comparison with other studies in which the effects of renewable and non-renewable energy consumption on economic growth were simultaneously investigated show that the results obtained here are consistent with those reported by Tiwari (2011) for 14 EU countries, Uçan et al. (2014) for 15 EU countries and Ito (2017) for 42 developed countries. However, the results are different from those by Menegaki (2011) who found no relationship between renewable energy consumption and economic growth and Furuoka (2017) who found that economic growth affects renewable energy consumption. Finding positive and significant relationship between renewable energy consumption and economic growth for post-transition EU countries in the long term is also found by Alper, Oguz (2016) for 7 new EU 
countries, Koçak and Şarkgüneşi (2017) for Bulgaria and Greece, Šimelytė and Dudzevičiūtė (2017) for 12 EU countries and Marinaș et al. (2018) for Hungary, Lithuania and Slovenia.

\section{Conclusion}

This article investigated the short and long-run impact of non-renewable and renewable energy consumption on economic growth in EU countries. The main aim of this study was to analyse whether energy sources contribute equally to economic growth and what is the difference in the use of individual energy sources in developed compared to post-transition EU countries. Using PMG estimator the results have confirmed the main hypothesis that in developed and post-transition EU countries, the change in the consumption of renewable and non-renewable energy per capita has a statistically significant impact on economic growth per capita. However, the impact of the consumption of non-renewable energy in posttransition EU countries is negative in the long run. It seems that post-transition EU countries managed to shift from less efficient and more polluting energy sources to more efficient energy options which became stimulus to economic growth. On the other hand in developed countries renewable energy consumption has a negative impact on economic growth. This might be a result of political decisions carried out in some developed EU countries which decreased or stopped further investments in the renewable sources of energy and encouraged investments in fossil fuels due to lower prices of oil.

In order to meet goals defined by the Kyoto Protocol and the Paris agreement, the EU has set different target values to be achieved by 2020 and 2030 among which are specific target values for increasing renewable energy production and energy efficiency. In December 2019 European Commission proposed The EU's Green Deal, which is a roadmap for how to reach the newly set climate goal of a 50-55 per cent emission reduction in emissions by 2030, as well as a net-zero emission economy by 2050 . It outlines policies and measures, including financial support, which should help enable the EU and its member states, in a collective effort, to reduce emissions sufficiently. To achieve these goals represents a particular challenge for the post-transition EU countries. Although energy intensity is still higher in the new Member States, it would be irresponsible to impose a reduction in energy consumption in those countries.

Given that consumption of renewable energy has positive impact on economic growth in post-transition EU countries, an active role of energy policy-makers in promoting and implementing such energy will have positive effects on the economy. Since infrastructure in post-transition EU countries is old and out-dated, there are essential investments in the development of renewable energy sector. Furthermore, 
financial and technical support from developed countries is necessary in order to accomplish goals set by Kyoto protocol and Paris agreement. Also, energy policies intended to increase the production and use of renewable energy will lower the current energy dependence of post-transition countries on energy-supplying states. Although the EU seeks to establish a single energy market and common energy targets for all Member States, energy policies have to be adjusted for the needs of post-transition EU countries. The government should choose the most appropriate incentive policies based on their relevant objectives in terms of renewable energy, the availability of renewable energy technology and the budget constraints in order to promote optimally the exploitation of renewable energy. To ease this "tradeoff" between energy consumption and economic growth, policy makers should implement energy policies and provide incentives that emphasise the structural changes towards more energy-efficient industries. New technology-intensive and energy-efficient industries complementary to developed service sector, could trigger sustainable economic growth.

Furthermore, economic growth should be decoupled from energy consumption to avoid negative impacts on economic activities resulting from EU directives enforcing reductions in energy use. Far from being conclusive, this study allows us to open new research directions in the field of multivariate causality among energy consumption, economic activity and $\mathrm{CO} 2$ emissions on dissagregated level and to assess public policies in the energy sector. Also it seems as a good practice to consider the different behavior of different sectors in both energy consumption analyses and in the energy conservation policy design.

\section{References}

Apergis, N., Payne, J. E. (2011) "Renewable and non-renewable electricity consumption-growth nexus: evidence from emerging market economies", Applied Energy, Vol. 88, No. 12, pp. 5226-5230, https://doi:10.1016/j.apenergy. 2011.06.041.

Apergis N., Payne J.E. (2012) "Renewable and non-renewable energy consumptiongrowth nexus: Evidence from a panel error correction model", Energy Economics, Vol. 34, No. 3, pp. 733-738, https://doi.org/10.1016/j.eneco. 2011.04.007.

Alper, A.,Oguz, O. (2016) "The role of renewable energy consumption in economic growth: Evidence from asymmetric causality", Renewable and Sustainable Energy Reviews, Vol. 60, pp. 953-959, http://dx.doi.org/10.1016/j. rser.2016.01.123.

Bercu, A. M., Paraschiv, G., Lupu, D. (2019) "Investigating the energy-economic growth-governance nexus: Evidence from Central and Eastern European 
countries", Sustainability, Vol. 11, No. 12, p. 3355, https://doi.org/10.3390/ su11123355.

Bhattacharya, M., Paramati, S.R., Ozturk I., Bhattacharya S. (2016) "The effect of renewable energy consumption on economic growth: Evidence from top 38 countries", Applied Energy, Vol. 162, pp. 733-741, http://dx.doi.org/10.1016/j. apenergy.2015.10.104.

Bowden, N., Payne, J.E. (2009) "The causal relationship between U.S. energy consumption and real output: A disaggregated analysis", Journal of Policy Modeling, Vol. 31, pp. 180-188, https://doi.org/10.1016/j.jpolmod.2008.09.001

Breitung J. (2001) "The Local Power of Some Unit Root Tests for Panel Data In Nonstationary Panels, Panel Cointegration, and Dynamic Panels", Advances in Econometrics, Baltagi B. (ed.), Amsterdam, Vol. 31, pp.161-178, https://doi. org/10.1016/S0731-9053(00)15006-6.

Costantini, V., Martini, C. (2010) "The causality between energy consumption and economic growth: A multi-sectoral analysis using non-stationary cointegrated panel data", Energy Economics, Vol. 32, No. 3, pp. 591-603, https://doi. org/10.1016/j.eneco.2009.09.013.

Dobnik, F. (2011) "Energy consumption and economic growth revisited: structural breaks and cross-section dependence", Available at SSRN 1981869, https://dx. doi.org/10.2139/ssrn.1981869.

European Commission (2019) The European Green Deal, EU Commission: Brussels, Belgium https://eur-lex.europa.eu/resource.html?uri=cellar:b828d1651c22-11ea-8c1f-01aa75ed71a1.0002.02/DOC_1\&format=PDF [Accessed: 15.10.2020].

European Council (2015) Energy Union: secure, sustainable, competitive, affordable energy for every European, https://ec.europa.eu/commission/ presscorner/detail/en/IP_15_4497 [Accessed: 15.01.2020].

Eurostat (2020) Supply, transformation and consumption of energy, by source, https://appsso.eurostat.ec.europa.eu/nui/show.do?dataset=nrg_cb_sff\&lang=en [Accessed: 15.01.2020].

Eurostat (2020) "The EU in the World", Eurostat Statistical Books. https://ec.europa. eu/eurostat/documents/3217494/10934584/KS-EX-20-001-EN-N.pdf/8ac3b6400c7e-65e2-9f79-d03f00169e17 (11.12.2020.) [Accessed: 15.01.2020].

Farfan Orozco, F. (2017) "Aging of European power plant infrastructure as an opportunity to evolve towards sustainability", International Journal of Hydrogen Energy, Vol. 42, pp. 18081-18091, https://doi.org/10.1016/j. ijhydene.2016.12.138.

Gemmell, N., Kneller, R., Sanz, I. (2016) "Does the Composition of Government Expenditure Matter for Long-Run GDP Levels?" Oxford Bulletin of Economics and Statistics, Vol. 78, No. 4, pp. 522-547, https://doi.org/10.1111/obes.12121. 
Hajko, V. (2014) "The Energy-GDP Nexus in EU Countries", Energy Studies Review, Vol. 20, No. 2, pp. 1-23, https://energystudiesreview.ca/esr/article/view/546/524.

Ito, $\mathrm{K}$. (2017) " $\mathrm{CO}_{2}$ emissions, renewable and non-renewable energy consumption, and economic growth: evidence from panel data for developing countries", International Economics, CEPII research center, No. 151, pp. 1-6, https://doi. org/10.1016/j.inteco.2017.02.001.

Im KS, Pesaran MH, Shin Y. (2003) "Testing for unit roots in heterogeneous panels", Journal of Econometrics, Vol. 115, Issue 1, pp. 53-74, https://doi. org/10.1016/S0304-4076(03)00092-7.

IEA (2018) World Energy Investment 2018, https://www.iea.org/reports/worldenergy-investment-2018 [Accessed: 15.04.2020].

IRENA (2015) Renewable Energy Target Setting, http://www.irena.org/ DocumentDownloads/Publications/IRENA_RE_Target_Setting_2015.pdf [Accessed: 15.01.2020].

Jebli, M. B., Youssef, S. B. (2015) "Output, renewable and non-renewable energy consumption and international trade: Evidence from a panel of 69 countries", Renewable Energy, Vol. 83, pp. 799-808, https://doi.org/10.1016/j.renene. 2015.04.061.

Koçak, E., Şarkgüneşi, A. (2017) "The renewable energy and economic growth nexus in Black Sea and Balkan countries," Energy Policy, Vol. 100, pp. 51-57, https://doi.org/10.1016/j.enpol.2016.10.007.

Kraft, J., Kraft, A. (1978) On the relationship between energy and GNP, Journal of Energy and Development, Vol. 3, No. 2, pp. 401-403, https://www.jstor.org/ stable/24806805?seq=1.

Lee, Y. M., Wang, K. M. (2015), "Dynamic heterogeneous panel analysis of the correlation between stock prices and exchange rates", Economic researchekonomska istraživanja, Vol. 28, No. 1, pp. 749-772, https://doi.org/10.1080/13 31677X.2015.1084889.

Levin A, Lin F, Chu C. "Unit Root Tests in Panel Data: Asymptotic and FiniteSample Properties", Journal of Econometrics 2002, Vol. 108, No. 1, pp. 1-24, https://doi.org/10.1016/S0304-4076(01)00098-7.

Maddala GS, Wu SA. (1999) "Comparative Study of Unit Root Tests with Panel Data and a New Simple Test", Oxford Bulletin of Economics and Statistics, Vol. 61, pp. 631-652, https://doi.org/10.1111/1468-0084.0610s1631.

Marinaș, M. C., Dinu, M., Socol, A. G., Socol, C. (2018), "Renewable energy consumption and economic growth. Causality relationship in Central and Eastern European countries" PloS one, Vol. 13, No. 10, e0202951 https://doi. org/10.1371/journal.pone.0202951.

Menegaki, A. N. (2011) "Growth and renewable energy in Europe: A random effect model with evidence for neutrality hypothesis", Energy Economics, Vol. 33, No. 2, pp. 257-263, https://doi.org/10.1016/j.eneco.2010.10.004. 
Menegaki, A. N. (2014) "On energy consumption and GDP studies; A meta-analysis of the last two decades", Renewable and Sustainable Energy Reviews, Vol. 29, pp. 31-36, https://doi.org/10.1016/j.rser.2013.08.081.

Narayan, P.K., Popp, S. (2012) "The energy consumption-real GDP nexus revisited: Empirical evidence from 93 countries", Economic Modelling, Vol. 29, No. 2, pp. 303-308, https://doi.org/10.1016/j.econmod.2011.10.016.

Ozturk, I. (2010) A literature survey on energy-growth nexus, Energy Policy, Vol. 38, No. 1, pp. 340-349, https://doi.org/10.1016/j.enpol.2009.09.024.

Ozturk, I.; Acaravci, A. (2010) "The causal relationship between energy consumption and GDP in Albania, Bulgaria, Hungary and Romania: Evidence from ARDL bound testing approach", Applied Energy, Vol. 87, No. 6, pp. 1938 1943, https://doi.org/10.1016/j.apenergy.2009.10.010.

Papiez M., Smiech, S., (2013) "Economic Growth and Energy Consumption in Post-Communist Countries: a Bootstrap Panel Granger Causality Analysis", Dynamic Econometric Models, Uniwersytet Mikolaja Kopernika, Vol. 13, pp. 51-68, http://dx.doi.org/10.12775/DEM.2013.003.

Pedroni, P. (1999) "Critical values for cointegration tests in heterogeneous panels with multiple regressors", Oxford Bulletin of Economics and statistics, Vol. 61, No.1, pp. 653-670, https://econpapers.repec.org/scripts/redir.pf?u=https\%3A\%2F $\% 2 \mathrm{Fweb}$.williams.edu\%2FEconomics $\% 2 \mathrm{Fwp} \% 2 \mathrm{Fpedronicriticalvalues.pdf;} \mathrm{h}=\mathrm{re}$ pec:wil:wileco:2000-02.

Pesaran HM, Shin Y, Smith RP (1999) "Pooled mean group estimation of dynamic heterogeneous panels", Journal of the American Statistical Association, Vol. 94, pp. 621-634, https://econpapers.repec.org/scripts/redir.pf?u=http $\% 3 \mathrm{~A} \% 2 \mathrm{~F} \% 2 \mathrm{~F}$ www.econ.ed.ac.uk\%2Fpapers\%2Fid16_esedps.pdf;h=repec:edn:esedps:16.

Pesaran, M. H., Smith, R. (1995) "Estimating long-run relationships from dynamic heterogeneous panels", Journal of econometrics, Vol. 68, No. 1, pp. 79-113, https://doi.org/10.1016/0304-4076(94)01644-F.

Pirlogea, C., Cicea, C. (2012) "Econometric perspective of the energy consumption and economic growth relation in European Union," Renewable and Sustainable Energy Reviews, Vol. 16, No. 8, pp. 5718-5726, https://doi.org/10.1016/j.rser.2012.06.010.

Salim, R. A., Hassan, K., Shafiei, S. (2014) "Renewable and non-renewable energy consumption and economic activities: Further evidence from OECD countries", Energy Economics, Vol. 44, pp. 350-360, https://doi.org/10.1016/j.eneco. 2014.05.001.

Sari, R., Soytas, U., (2007) "The growth of income and energy consumption in six developing countries", Energy Policy, Vol. 35, pp. 889-898, https://oi.org/ 10.1016/j.enpol.2006.01.021.

Sharma, S. S. (2010) "The relationship between energy and economic growth: Empirical evidence from 66 countries" Applied energy, Vol. 87, No. 11, pp. 3565-3574, https://doi.org/10.1016/j.apenergy.2010.06.015. 
Sulaiman, C., Abdul-Rahim, A. S. (2020) "The Impact of Wood Fuel Energy on Economic Growth in Sub-Saharan Africa: Dynamic Macro-Panel Approach" Sustainability, Vol. 12, No. 8, p. 3280, https://doi.org/10.3390/su12083280.

Šimelytė, A., Dudzevičiūtè, G. (2017) "Consumption of renewable energy and economic growth" In Contemporary issues in business, management and education'2017: 5th international scientific conference, 11-12 May 2017, Vilnius Gediminas Technical University: conference proceedings (1-10). VGTU Press, https://doi.org/10.3846/cbme.2017.048.

Tiwari A.K., (2011) Comparative performance of renewable and non-renewable energy source on economic growth and $\mathrm{CO}_{2}$ emissions of Europe and Eurasian countries: A PVAR approach", Economics Bulletin, Vol. 31, No. 3, pp. 23562372, https://econpapers.repec.org/scripts/redir.pf? $\mathrm{u}=\mathrm{http} \% 3 \mathrm{~A} \% 2 \mathrm{~F} \% 2 \mathrm{Fwww}$. accessecon.com\%2FPubs\%2FEB\%2F2011\%2FVolume31\%2FEB-11-V31I3-P212.pdf; h=repec:ebl:ecbull:eb-11-00479.

Tugcu, C.T., Ozturk, I., Aslan, A. (2012) "Renewable and non-renewable energy consumption and economic growth relationship: Evidence from G7 countries", Energy Economics, Vol. 34, No. 6, pp. 1942-1950, https://doi.org/10.1016/j. eneco.2012.08.021.

Uçan, O., Aricioglu, E., Yucel, F. (2014) Energy Consumption and Economic Growth Nexus: Evidence from Developed Countries in Europe, International Journal of Energy Economics and Policy, Vol. 4, No. 3, pp. 411-419, http:// www.econjournals.com/index.php/ijeep/article/download/848/476.

Vlahinić-Dizdarević, N. (2011) Restrukturiranje i liberalizacija tržišta električne energije: Gdje je Hrvatska. Računovodstvo i financije, God. 57, pp. 99-104, https://bib.irb.hr/datoteka/522647.vlahinic_dizdarevic-rif.pdf.

World Bank Group (2018) Global Economic Prospects, Broad-based upturn, but for how long,https://openknowledge.worldbank.org/bitstream/handle/10986/28932/ 9781464811630.pdf [Accessed: 15.04.2020]. 


\title{
Utjecaj potrošnje energije na ekonomski rast u razvijenim i post-tranzicijskim zemljama Europske unije
}

\author{
Tanja Fatur Šikic ${ }^{1}$
}

\begin{abstract}
Sažetak
Cilj ovog istraživanja bio je empirijski istražiti utjecaj potrošnje obnovljivih $i$ neobnovljivih izvora energije na ekonomski rast. Analiza je provedena na podacima za 16 razvijenih EU država u razdoblju od 1990. do 2018. te za 11 posttranzicijskih EU država u razdoblju od 1995. do 2018. Dobiveni rezultati uspoređeni su s rezultatima dobivenim za razdoblje do 2014.godine. Za kvantificiranje kratkoročnog $i$ dugoročnog utjecaja, primijenjen je združeni procjenitelj aritmetičke sredine grupe (PMG). Prema empirijskim rezultatima potrošnja oba izvora energije u dugom roku značajno utječe na ekonomski rast u obje skupine zemalja. Međutim, rezultati se razlikuju između razvijenih i posttranzicijskih EU zemalja. U razvijenim EU zemljama potrošnja obnovljivih izvora energije ima negativan utjecaj na ekonomski rast, dok potrošnja neobnovljivih izvora energije ima pozitivan utjecaj. U post-tranzicijskim EU zemljama rezultati su suprotni, što znači da u tim zemljama postoji tendencija prelaska s manje učinkovitih $i$ onečišćujućih izvora energije na učinkovitije energetske opcije koje mogu biti poticaj ekonomskom rastu.
\end{abstract}

Ključne riječi: potrošnja obnovljivih i neobnovljivih izvora energije, ekonomski rast, razvijene i post-tranzicijske EU zemlje

JEL klasifikacija: Q43, O44, C33 


\section{Appendices}

Table 1A: Descriptive statistics

\begin{tabular}{|l|l|c|c|c|r|r|}
\hline \multirow{5}{*}{ EU16 } & Variable & Obs & Mean & Std. Dev. & \multicolumn{1}{c|}{ Min } & \multicolumn{1}{c|}{ Max } \\
\cline { 2 - 7 } & GDP & 459 & 41166.48 & 18299.13 & 6539.951 & 111968.4 \\
\cline { 2 - 7 } & GFCF & 464 & 8576.565 & 3686.422 & 2564.02 & 24856 \\
\cline { 2 - 7 } & LABOR & 464 & 0.481102 & 0.039781 & 0.396179 & 0.558528 \\
\cline { 2 - 7 } & NRE & 459 & 3.129299 & 1.436152 & 1.371544 & 9.491975 \\
\cline { 2 - 7 } & RE & 459 & 0.432392 & 0.498048 & 0.006681 & 2.137595 \\
\hline \multirow{5}{*}{ EU11 } & Variable & Obs & Mean & Std. Dev. & Min & \multicolumn{1}{c|}{ Max } \\
\cline { 2 - 7 } & GDP & 253 & 12895.12 & 5148.539 & 3756.751 & 26768.39 \\
\cline { 2 - 7 } & GFCF & 253 & 2977.71 & 1413.214 & 127.49 & 7445.37 \\
\cline { 2 - 7 } & LABOR & 253 & 0.477273 & 0.030342 & 0.389806 & 0.533005 \\
\cline { 2 - 7 } & NRE & 251 & 1.924885 & 0.670702 & 0.476456 & 3.755915 \\
\cline { 2 - 7 } & RE & 251 & 0.324599 & 0.188089 & 0.05702 & 0.99635 \\
\hline
\end{tabular}

Table 2A: Diagnostic tests

\begin{tabular}{|l|c|c|}
\hline & EU16 & EU11 \\
\hline Modified Wald test & -1.5846 & -0.78768 \\
\hline Breusch-Pagan test & 213.1929 & 90.71792 \\
\hline Pesaran LM Normal & $2.807478 * * *$ & 1.009105 \\
\hline
\end{tabular}

Note: $* * *$ denote significant at $1 \%$; results for $\mathrm{H} 0$ of Modified Wald test: $\operatorname{sigma}(\mathrm{i})^{\wedge} 2=\operatorname{sigma}^{\wedge} 2$ for all I; results for $\mathrm{H} 0$ of Pesaran and Breusch-Pagan LM tests: residuals are not correlated

Source: Author's calculation 